\title{
Possible role of catecholamines, corticosteroids, and potassium in production of electrocardiographic abnormalities associated with subarachnoid haemorrhage
}

\author{
J. M. Cruickshank, G. Neil-Dwyer, and A. W. Stott \\ From Wessex Cardiac and Thoracic Centre, Western Hospital; Wessex Neurosurgical Unit, General Hospital, \\ Southampton; and Biochemistry Department, Scarborough Hospital, Yorks
}

In a study of 40 patients with subarachnoid haemorrhage, of whom 24 were women of mean age 42 and I6 men of mean age 4I, an attempt has been made to correlate electrocardiographic abnormalities with urinary normetanephrins and metanephrins, plasma cortisol, and with serum and total body potassium levels. Urinary normetanephrins and metanephrins, and plasma cortisol values were significantly raised in 19 patients with abnormal electrocardiograms compared with the 8 patients with normal cardiograms. In the former group urinary catecholamine and plasma cortisol concentrations remained at abnormally high levels throughout a 2week observation period. Electrocardiographic features which showed a strong correlation with high urinary normetanephrin levels were a short $P R$ interval and peaking of the $T$ waves, and with high urinary metanephrin levels peaking of the $P$ waves. Weaker, though significant, relations with high urinary catecholamines were shown by $T$ wave inversion, long $Q T c$, tall $U$ waves, and $Q$ waves. High plasma cortisol levels were significantly related to peaking of the $P$ waves, a short $P R$ interval, and peaking of the $T$ waves. No significant differences in serum potassium levels in patients with either normal or abnormal electrocardiograms were revealed. Thirteen cases had total body exchangeable potassium measured about one week after subarachnoid haemorrhage, and abnormally low or low normal levels were observed in 9 of the 10 patients with abnormal or changing electrocardiograms. A second estimation of total body potassium in 6 cases, several months after the subarachnoid haemorrhage, showed higher values in 5 cases with one low normal remaining unchanged. No second estimation fell outside the normal range.

It was considered likely that the high urinary catecholamine and plasma cortisol levels arose from hypothalamic stimulation resulting from the haemorrhage. The possible mode of action of catecholamines upon the heart was discussed, with accent on the sensitizing effect of corticosteroids. This permissive role of corticosteroids probably stems from their ability to cause potassium deficiency, not reflected in serum levels, where a low myocardial intracellular potassium renders the heart susceptible to the necrotizing effect of catecholamines. It is, therefore, suggested that catecholamines, potentiated by corticosteroids and the associated potassium deficiency, are responsible for electrocardiographic abnormalities associated with subarachnoid haemorrhage, though a cause-and-effect relation has not been proved.

Electrocardiographic abnormalities occurring with subarachnoid haemorrhage were first described by Byer, Ashman, and Toth (1947). Their observations have since been confirmed by many studies (Hersch, I964; Kreus, Kemilä, and Takala, I969; Hunt, McRae, and Zapf, 1969) but the mechanism by

Received 26 October 1973. which the abnormalities are brought about has been a matter for speculation. Possible explanations have included hypokalaemia (Hersch, I964), stimulation of area 13 under the frontal lobes (Cropp and Manning, I960), hypertension (Kreus et al., 1969), ischaemic heart disease (Sarner and Crawford, 1965), increased parasympathetic drive (Shuster, I960), and increased sympathetic drive to the heart 
(Tomomatsu et al., 1964). There is a good deal of indirect evidence to support this last suggestion (Lepeschkin et al., 1960; Melville et al., 1963; Reichenbach and Benditt, 1970; Sparks et al., 1970; Hawkins and Clower, 1971; Hunt and Gore 1972). In contrast, direct evidence is scanty. Tomomatsu et al. (1964) and Eisalo, Peräsalo and Halonen (1972) estimated urinary catecholamines in a small number of patients with subarachnoid haemorrhage, and neither group demonstrated a correlation between electrocardiographic abnormalities and catecholamine levels. Russian workers (Iliynski and Astrakhantseva, 1967) showed a correlation in a minority of cases, but little detail was given. Though most studies have ruled out hypokalaemia as the cause (Wasserman et al., 1956; Kung et al., 1958; Finkelstein and Nigaglioni, 196I; Lichtlen and Schaub, I962; Kreus et al., 1969), observations on total body exchangeable potassium have not been made. The integrity of the myocardial cell depends, among other things, upon the ratio of potassium concentrations inside and outside the cell membrane (Sodi-Pallares et al., 1963). Thus changes in total body potassium, not necessarily reflected in serum potassium levels (Croxson, Neutze, and John, 1972; Lockey et al., 1966) have a pronounced effect upon the myocardial cell. Potassium deficiency, leading to low myocardial intracellular potassium, has been noted to sensitize the heart to the harmful necrotizing effects of catecholamines (Bajusz and Jasmin, 1964; Selye, 1970).

The present study was designated to investigate the relation between serially estimated urinary catecholamine levels and electrocardiographic abnormalities in subarachnoid haemorrhage. Adrenocortical activity was assessed, by measuring plasma cortisol levels, because corticosteroids are known to potentiate the effect of catecholamines upon the cardiovascular system (Raab, 1966; Selye, 1970). The interrelation between serum potassium levels, total body exchangeable potassium, and electrocardiographic abnormalities occurring in subarachnoid haemorrhage, was also studied.

\section{Subjects and methods}

The subarachnoid haemorrhage cases, proven by lumbar puncture, comprised 46 consecutive admissions to the Wessex Neurosurgical Centre. Six had a history of either hypertension or ischaemic heart disease and were omitted from the series. Of the remaining 40 cases, 16 were men with a mean age of $4 \mathrm{I}$ (range $13-56$ ) and 24 women with a mean age of 42 (range II-65). No patient was on diuretic therapy. All were taking a normal hospital diet.

On days 1,2 , and 3 after admission, and thereafter every 2 to 3 days over a 2 -week period, the following investigations were done between 8.00 and 8.30 a.m. I) A I2-lead electrocardiogram which was read by the same person (J.M.C.) each time without knowledge of results of other investigations. Peaked $P$ waves were defined as $\mathbf{P}$ waves taller than $2.5 \mathrm{~mm}$; $P$ mitrale as a bifid $P$ wave wider than O.IO sec; ST depression greater than I $\mathrm{mm}$ and elevation greater than $2.5 \mathrm{~mm}$ were regarded as abnormal; $T$ wave peaking was defined as a $T / R$ ratio in $\mathrm{V}_{4}$ exceeding 0.6 ; the QTc was measured only when the $U$ wave was visible, $0.43 \mathrm{sec}$ being regarded as the upper limit of normal; I mm was regarded as the upper limit of normal for $U$ wave magnitude. 2) A 24hour urine collection was started for estimation of normetanephrins and metanephrins (breakdown products of noradrenaline and adrenaline, respectively) by the method of Stott and Robinson (1966). The upper limit of normal for both is $300 \mu \mathrm{g}$ per 24 hours. 3) A venous blood sample was taken for (a) plasma cortisol estimation by the fluorimetric method of Mattingly (1962), the upper limit of normality being taken as $20 \mu \mathrm{g}$ per $100 \mathrm{ml}$. (b) Serum potassium, the normal range being $3.5-5.0 \mathrm{mEq} / 1.4$ ) In 13 cases total body exchangeable potassium levels were estimated by an isotopic dilution method (Flear et al., 1963): after 24 hours for equilibrium, the specific activity of 2 urine specimens passed within I hour of each other was measured. The error for the method is 5 per cent (Moore, 1963). Observed results were expressed in $\mathrm{mEq}$ and compared with the predicted result ( \pm 2 SD) for age, sex, and weight of the patient, as read from regression lines based on age-grouped normal men and women (Moore, 1963). The ratio of observed total potassium to predicted total potassium ( $\mathrm{K}$ obs/ $\mathrm{K}$ pred), was a convenient means of expressing body potassium status. Total body potassium measurements were in most cases made about $I$ week after the haemorrhage. In 6 cases with low levels a second estimation was made about 4 months later.

The 40 cases were divided into 3 groups: Cases with all normal electrocardiograms, cases with all abnormal electrocardiograms, and cases with changing electrocardiograms where some were normal and others abnormal. In the 8 cases with normal electrocardiograms, 6 were men of mean age 36 (range 13-54) and 2 were women of mean age 43 (range 42-44). The I9 cases in the abnormal electrocardiogram group comprised 5 men of mean age 48 (range 43-56) and 14 women of mean age 46 (range I6-65). The last group of 13 with changing electrocardiograms included 5 men of mean age 40 (range 16-54) and 8 women of mean age 35 (range II-59).

\section{Results}

A total of 197 electrocardiograms was recorded, an average of 5 per patient. One hundred and fifty-two 24-hour urinary catecholamine and 89 plasma cortisol estimations were made. Types of electrocardiographic abnormality seen and their incidence are shown in Table $\mathrm{I}$, where numbers indicate cases who showed the particular abnormality on at least 2 occasions.

Mean urinary catecholamine and plasma cortisol levels in the electrocardiogram groups are shown in Table 2. Comparisons of the means were made by 
TABLE I Types of electrocardiographic abnormality and their incidence in 40 cases

\begin{tabular}{lrr}
\hline Type of abnormality & No. of cases & $\%$ \\
\hline Tachycardia (>100/min) & 13 & 33 \\
Bradycardia (<60/min) & 9 & 23 \\
Extrasystoles & 5 & 13 \\
Wandering pacemaker & 2 & 5 \\
Peaked P waves & 16 & 41 \\
P mitrale & 3 & 8 \\
Short PR (<0.13 sec) & 10 & 25 \\
Q waves & 2 & 5 \\
Raised ST segment & 13 & 33 \\
Depressed ST segment & 3 & 8 \\
Coved ST & 6 & 16 \\
Flat T & 7 & 18 \\
Inverted T & 14 & 36 \\
Peaked T & 8 & 20 \\
Tall U (>0.1 mV) & 13 & 33 \\
Long QTc $(>0.43$ sec) & 22 & 55 \\
& & \\
\hline
\end{tabular}

the Student ' $t$ ' test and the resulting $P$ values are indicated in Table 3. The electrocardiographic features were analysed separately in an attempt to relate high urinary catecholamine and plasma cortisol levels to particular types of abnormality. Features having a significant relation with high urinary catecholamine levels are shown in Table 4. No statistically significant relation could be shown in the case of bradycardia, raised ST segments, coved ST segments, depressed ST segments, ventricular extrasystoles, or wandering pacemaker. The 3 components with a significant relation to high plasma cortisol levels are seen in Table 5.

Electrocardiographic components that were easily measured, namely the height of the $\mathbf{P}$ wave, $P R$ interval, QTc, and height of $U$ waves, were correlated with urinary catecholamine and plasma cortisol levels observed at the time of recording the electrocardiogram, and correlation coefficients ( $r$ ) and $P$ values are illustrated in Table 6. The QTc
TABLE $3 P$ values for comparisons of the mean values of normetanephrin, metanephrin, total catecholamines, and plasma cortisol levels in the 3 electrocardiographic groups (Table 2)

\begin{tabular}{lllll}
\hline $\begin{array}{l}\text { Electro- } \\
\text { cardio- } \\
\text { graphic } \\
\text { groups }\end{array}$ & $\begin{array}{l}\text { Norme- } \\
\text { tanephrin }\end{array}$ & $\begin{array}{l}\text { Metane- } \\
\text { phrin }\end{array}$ & $\begin{array}{l}\text { Total } \\
\text { catechol- } \\
\text { amines }\end{array}$ & $\begin{array}{l}\text { Plasma } \\
\text { cortisol }\end{array}$ \\
\hline $\begin{array}{l}\text { Normal } \\
\text { against } \\
\text { abnormal }\end{array}$ & $\mathrm{P}<0.01$ & $\mathrm{P}<0.001$ & $\mathrm{P}<0.00 \mathrm{I}$ & $\mathrm{P}<0.001$ \\
$\begin{array}{l}\text { Normal } \\
\text { against } \\
\text { changing }\end{array}$ & $\mathrm{N} . \mathrm{S}$. & $\mathrm{P}<0.05$ & $\mathrm{P}<0.05$ & $\mathrm{P}<0.01$ \\
$\begin{array}{l}\text { Changing } \\
\text { against } \\
\text { abnormal }\end{array}$ & $\mathrm{P}<0.01$ & $\mathrm{P}<0.01$ & $\mathrm{P}<0.01$ & $\mathrm{~N} . \mathrm{S}$. \\
\hline
\end{tabular}

and $U$ wave height showed no significant correlation with urinary catecholamine and plasma cortisol levels.

The relation between the time of the observations from the day of the subarachnoid haemorrhage on the one hand and urinary catecholamine and plasma cortisol levels on the other is shown in Fig. I. It is apparent that in the normal electrocardiogram group, though the numbers of observations are relatively small, catecholamine and cortisol levels were within, or marginally above, the normal range throughout the whole period of 2 weeks or more. In contrast, in the abnormal group catecholamine and cortisol levels remained at abnormally high levels over the same period.

Mean serum potassium levels in the 3 electrocardiographic groups are shown in Table 7. There is no significant difference between the levels in the 3 groups and all are in the normal range. The total body potassium was normal in the normal electrocardiogram group but, with one exception

TABLE 2 Relation between electrocardiogram and 24-hour urinary normetanephrin, metanephrin, total catecholamines, and plasma cortisol.

\begin{tabular}{|c|c|c|c|c|}
\hline Electrocardiogram & $\begin{array}{l}\text { Mean urinary } \\
\text { normetanephrin } \\
(\mu g / 24 \mathrm{hr})\end{array}$ & $\begin{array}{l}\text { Mean urinary } \\
\text { metanephrin } \\
(\mu g / 24 h r)\end{array}$ & $\begin{array}{l}\text { Mean urinary total } \\
\text { catecholamines } \\
(\mu \mathrm{g} / 24 \mathrm{hr})\end{array}$ & $\begin{array}{l}\text { Mean plasma } \\
\text { cortisol } \\
(\mu g / 100 \mathrm{ml})\end{array}$ \\
\hline $\begin{array}{l}\text { All normal } \\
\text { Changing } \\
\text { All abnormal }\end{array}$ & $\begin{array}{l}267( \pm I 53) \\
n=23 \\
320( \pm 143) \\
n=52 \\
479( \pm 282) \\
n=77\end{array}$ & $\begin{array}{l}218( \pm 125) \\
n=23 \\
290( \pm 127) \\
n=52 \\
376( \pm 158) \\
n=77\end{array}$ & $\begin{array}{l}485( \pm 192) \\
n=23 \\
610( \pm 232) \\
n=52 \\
855( \pm 357) \\
n=77\end{array}$ & $\begin{array}{l}15 \cdot 0( \pm 6 \cdot 33) \\
n=16 \\
22 \cdot 9( \pm 9 \cdot 4 I) \\
n=30 \\
25 \cdot 8( \pm 9 \cdot 4 I) \\
n=48\end{array}$ \\
\hline
\end{tabular}

$\mathbf{n}=$ number of observations.

Standard deviation is expressed as \pm . 
TABLE 4 Relation between mean 24-hour urinary normetanephrin, and total catecholamine levels $(\mu g)$ and the various electrocardiographic abnormalities.

\begin{tabular}{|c|c|c|c|}
\hline $\begin{array}{l}\text { Electrocardio- } \\
\text { graphic } \\
\text { abnormality }\end{array}$ & $\begin{array}{l}\text { Norme- } \\
\text { tanephrin }\end{array}$ & $\begin{array}{l}\text { Metane- } \\
\text { phrin }\end{array}$ & Total \\
\hline $\begin{array}{l}\text { Tachycardia } \\
\mathrm{n}=63\end{array}$ & $\begin{array}{l}453 \\
( \pm 260)\end{array}$ & $\begin{array}{l}358 \\
( \pm 15 I)\end{array}$ & $\begin{array}{l}8 \mathrm{II} \\
( \pm 376)\end{array}$ \\
\hline No tachycardia & 347 & 301 & 648 \\
\hline $\mathrm{n}=89$ & $( \pm 188)$ & $( \pm 137)$ & $( \pm 278)$ \\
\hline $\mathbf{P}$ value & $<0.01$ & $<0.05$ & $<0.01$ \\
\hline Peaked $P$ wave & 452 & 366 & 818 \\
\hline $\mathrm{n}=65$ & $( \pm 263)$ & $( \pm 134)$ & $( \pm 359)$ \\
\hline $\begin{array}{l}\text { Non-peaked } P \text { wave } \\
n=87\end{array}$ & $\begin{array}{l}347 \\
( \pm 187)\end{array}$ & $\begin{array}{l}292 \\
( \pm 146)\end{array}$ & $\begin{array}{l}639 \\
(+29 I)\end{array}$ \\
\hline $\mathbf{P}$ value & $<0.01$ & $<0.01$ & $<0.01$ \\
\hline PR $<0.13 \mathrm{sec}$ & 428 & 321 & 749 \\
\hline $\begin{array}{l}n=60 \\
P R>0.17 \mathrm{sec}\end{array}$ & $\begin{array}{l}( \pm 260) \\
252\end{array}$ & $\begin{array}{l}( \pm I 12) \\
246\end{array}$ & $\begin{array}{l}( \pm 350) \\
498\end{array}$ \\
\hline $\mathbf{n}=\mathbf{2} \mathrm{I}$ & $( \pm 109)$ & $( \pm 103)$ & $( \pm 165)$ \\
\hline $\mathbf{P}$ value & $<0.01$ & $<0.05$ & $<0.01$ \\
\hline Peaked T & 528 & 384 & 912 \\
\hline $\mathrm{n}=30$ & $( \pm 307)$ & $( \pm \mathbf{I 7 9})$ & $( \pm 444)$ \\
\hline Non-peaked T & 360 & 310 & 670 \\
\hline$n=122$ & $( \pm 190)$ & $( \pm 132)$ & $\begin{array}{l}( \pm 280) \\
<0.01\end{array}$ \\
\hline $\begin{array}{l}\text { P value } \\
\text { Inverted } T\end{array}$ & $\begin{array}{l}<0.001 \\
431\end{array}$ & $\begin{array}{l}<0.05 \\
348\end{array}$ & $\begin{array}{l}<0.01 \\
779\end{array}$ \\
\hline $\begin{array}{l}\text { Inverted } 1 \\
n=80\end{array}$ & $\begin{array}{l}431 \\
( \pm 244)\end{array}$ & $\begin{array}{l}348 \\
( \pm 163)\end{array}$ & $\begin{array}{l}779 \\
( \pm 363)\end{array}$ \\
\hline Non-inverted $\mathrm{T}$ & 352 & 297 & 649 \\
\hline $\mathrm{n}=72$ & $( \pm 198)$ & $( \pm 116)$ & $( \pm 283)$ \\
\hline $\mathbf{P}$ value & $<0.05$ & $<0.05$ & $<0.05$ \\
\hline QTc $>0.43 \mathrm{sec}$ & $44 \mathrm{I}$ & $36 \mathrm{I}$ & 802 \\
\hline $\begin{array}{l}\mathrm{n}=5 \mathrm{I} \\
\text { OTc }<0.42 \mathrm{sec}\end{array}$ & $( \pm 255)$ & $( \pm \mathrm{I} 47)$ & $( \pm 360)$ \\
\hline $\begin{array}{l}\text { QTc }<0.42 \mathrm{sec} \\
\mathrm{n}=\mathrm{IOI}\end{array}$ & $\begin{array}{l}369 \\
( \pm 208)\end{array}$ & $\begin{array}{l}307 \\
( \pm 140)\end{array}$ & $\begin{array}{l}676 \\
( \pm 308)\end{array}$ \\
\hline $\mathbf{P}$ value & N.S. & $<0.05$ & $<0.05$ \\
\hline $\mathrm{U}$ wave $>0.1 \mathrm{mV}$ & 428 & 343 & 771 \\
\hline$n=62$ & $( \pm 242)$ & $( \pm$ I59) & $( \pm 382)$ \\
\hline $\mathrm{U}$ wave $<0 . \mathrm{I} \mathrm{mV}$ & 368 & 312 & 680 \\
\hline $\mathrm{n}=90$ & $( \pm 211)$ & $( \pm 133)$ & $( \pm 288)$ \\
\hline $\mathbf{P}$ value & N.S. & N.S. & $<0.05$ \\
\hline$Q$ waves & 566 & 472 & 1038 \\
\hline $\mathrm{n}=8$ & $( \pm 444)$ & $( \pm 258)$ & $( \pm 683)$ \\
\hline No $Q$ waves & 395 & 325 & 720 \\
\hline $\mathrm{n}=\mathrm{I} 44$ & $( \pm 228)$ & （土 I49） & $( \pm 334)$ \\
\hline $\mathbf{P}$ value & $<0.05$ & $<0.05$ & $<0.05$ \\
\hline
\end{tabular}

$\mathrm{n}=$ number of observations.

Standard deviation is shown as \pm .
(Case I I), was abnormally low or low normal in the changing and abnormal electrocardiogram groups (Fig. 2 and Table 8). Serum potassium levels do not appear to reflect total body potassium (Table 8). Of the 9 cases with abnormally low or low normal body potassium estimations, 6 had repeat measurements several months later (mean of 5 months, range 3 to Io months). In 5 of these 6 cases, 3 with abnormally low and 2 with low normal levels, total body potassium levels had increased so that now all fell within the normal range for the particular weight (Fig. 2 and Table 8); the sixth patient (Case 8) showed a slightly decreased level but the difference was within the 5 per cent error for the method. All 6 cases had normal electrocardiograms at follow-up. When the estimations of total body potassium made within days of the subarachnoid haemorrhage are compared with those made months after the haemorrhage, the difference is statistically significant.

\section{Discussion}

Interpretation of the significance of 24-hour urinary catecholamine levels should be cautious. While urinary levels to some extent represent an overall estimate of sympathetic activity they are unlikely to reflect the influence of transitory changes. They are also dependent upon renal blood flow and function (Fluck, 1972). On balance, 24-hour urinary levels are possibly preferable to plasma levels which reflect the result of biosynthesis, catabolism, uptake, and release at the time of sampling, and may vary rapidly making interpretation of the significance of plasma catecholamine plasma levels difficult.

The three electrocardiographic groups were not homogeneous. The normal group contained a relatively small number of cases, with a preponderance of men; and the reverse was true for the abnormal and changing groups. A possible contribution of ischaemic heart disease to the electrocardiographic abnormalities could not be ruled out as there was a greater number of older patients in the abnormal

TABLE 5 Relation between plasma cortisol and electrocardiographic abnormalities

\begin{tabular}{|c|c|c|c|c|c|c|}
\hline $\begin{array}{l}\text { Electrocardiographic } \\
\text { abnormality }\end{array}$ & $\begin{array}{l}\text { Peaked } \\
P \text { wave } \\
n=40\end{array}$ & $\begin{array}{l}\text { Non-peaked } \\
P \text { wave } \\
n=49\end{array}$ & $\begin{array}{l}P R<O \cdot I 3 \\
\sec \\
n=I I\end{array}$ & $\begin{array}{l}P R>0.17 \\
\sec \\
n=2 I\end{array}$ & $\begin{array}{l}\text { Peaked } \\
T \text { wave } \\
n=2 I\end{array}$ & $\begin{array}{l}\text { Non-peaked } \\
T \text { wave } \\
n=68\end{array}$ \\
\hline $\begin{array}{l}\text { Plasma } \\
\text { cortisol } \\
\text { ( } \mu \mathrm{g} / \mathrm{I} 00 \mathrm{ml}) \\
\mathbf{P} \text { value }\end{array}$ & $\begin{array}{l}27.0 \\
( \pm 10.8) \\
P<0.01\end{array}$ & $\begin{array}{l}20 \cdot 7 \\
( \pm 8 \cdot 9)\end{array}$ & $\begin{array}{l}27.5 \\
( \pm 10.0) \\
P<0.01\end{array}$ & $\begin{array}{l}18 \cdot 9 \\
( \pm 7 \cdot 5)\end{array}$ & $\begin{array}{l}27.3 \\
( \pm 7.8) \\
P<0.05\end{array}$ & $\begin{array}{l}2 I \cdot 9 \\
( \pm 10 \cdot 1)\end{array}$ \\
\hline
\end{tabular}

$\mathrm{n}=$ number of observations.

Standard deviation shown as \pm . 


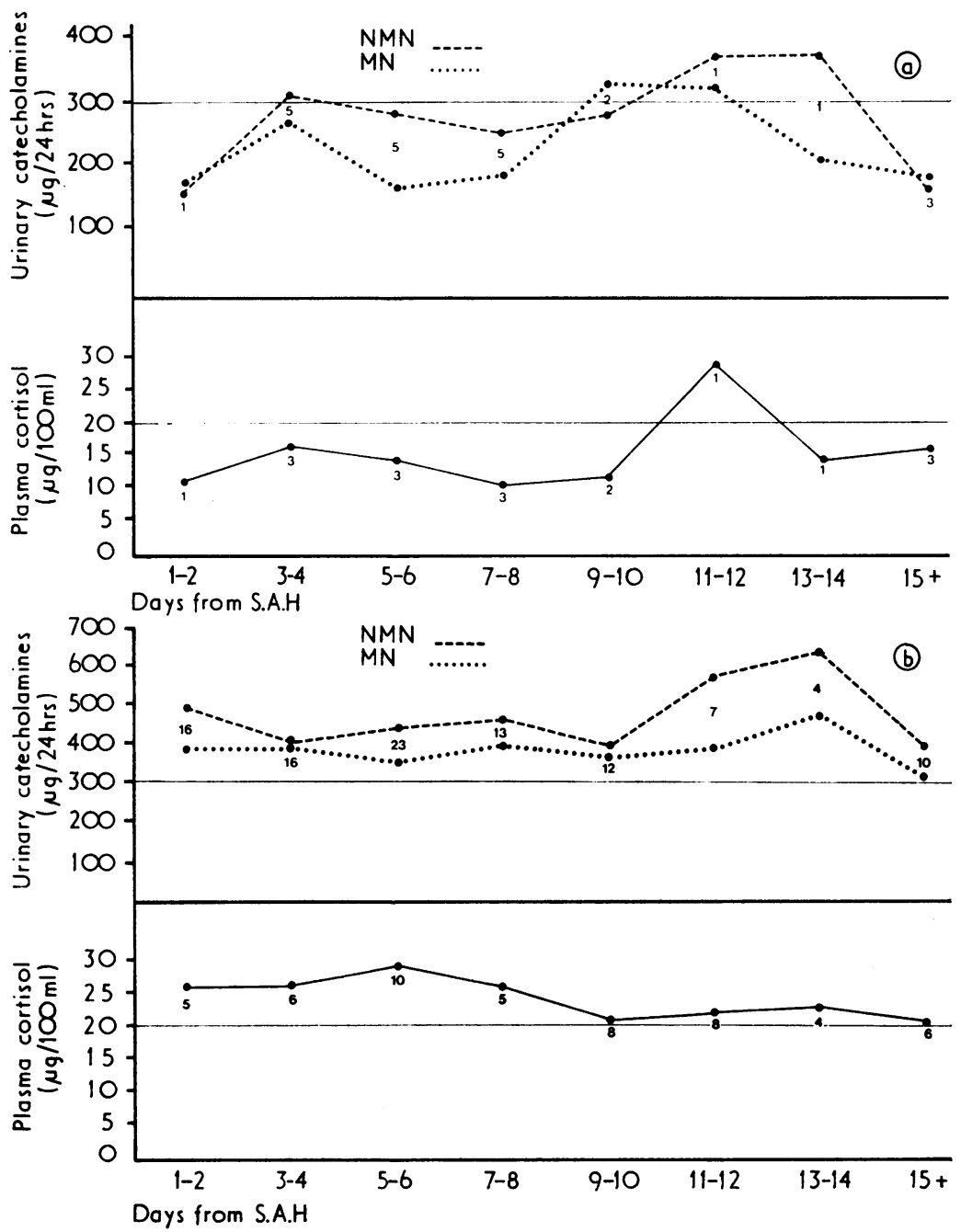

FIG. I Mean urinary normetanephrins (NMN), metanephrins (MN) in $\mu \mathrm{g} / 24$ hours, and plasma cortisol $(\mu \mathrm{g} / \mathrm{roo} \mathrm{ml}$ ) levels in relation to time after S.A.H., a) in group with all normal electrocardiograms; and b) in group with all abnormal electrocardiograms. The number of observations is shown.

TABLE 6 Correlation between height of $P$ wave and length of $P R$ interval, and normetanephrin, metanephrin, total catecholamine, and plasma cortisol level

\begin{tabular}{lllll}
\hline $\begin{array}{l}\text { Electrocardio- } \\
\text { graphic } \\
\text { component }\end{array}$ & $\begin{array}{l}\text { Normetanephrin } \\
n=152\end{array}$ & $\begin{array}{l}\text { Metanephrin } \\
n=152\end{array}$ & $\begin{array}{l}\text { Total } \\
\text { catecholamines } \\
n=152\end{array}$ & $\begin{array}{l}\text { Plasma cortisol } \\
n=89\end{array}$ \\
\hline $\begin{array}{l}\text { Height of } \\
\text { P wave }\end{array}$ & $\mathrm{r}=0.16$ & $\mathrm{r}=0.30$ & $\mathrm{r}=0.25$ & $\mathrm{r}=0.27$ \\
$\begin{array}{l}\mathrm{P} \text { value } \\
\text { PR interval }\end{array}$ & $\mathrm{P}=0.05$ & $\mathrm{P}=-0.00 \mathrm{r}$ & $\mathrm{P}>0.0 \mathrm{I}$ & $\mathrm{P}<0.01$ \\
P value & $\mathrm{P}<0.05$ & $\mathrm{r}=-0.1 \mathrm{I}$ & $\begin{array}{l}\mathrm{r}=-0.17 \\
\mathrm{P}<0.05\end{array}$ & $\begin{array}{l}\mathrm{r}=-0.16 \\
\mathrm{~N} . \mathrm{S} .\end{array}$ \\
\hline
\end{tabular}

$\mathbf{r}=$ correlation coefficient

$\mathrm{n}=$ number of observations. 
TABLE 7 Serum potassium levels in the 3 electrocardiographic groups

\begin{tabular}{|c|c|c|c|c|}
\hline $\begin{array}{l}\text { Potassium } \\
\text { levels }\end{array}$ & & $\begin{array}{l}\text { Normal } \\
\text { electro- } \\
\text { cardiograms } \\
\text { ( } 8 \text { cases) }\end{array}$ & $\begin{array}{l}\text { Changing } \\
\text { electro- } \\
\text { cardiograms } \\
\text { (I } 3 \text { cases) }\end{array}$ & $\begin{array}{l}\text { Abnormal } \\
\text { electro- } \\
\text { cardiograms } \\
\text { (19 cases) }\end{array}$ \\
\hline $\begin{array}{c}\text { Serum K } \\
\text { level } \\
(\mathrm{mEq} / \mathrm{l} .)\end{array}$ & $\underset{\text { mean }}{\mathbf{n}}$ & $\begin{array}{l}22 \\
3.8 \\
( \pm 0.98)\end{array}$ & $\begin{array}{l}62 \\
3.7 \\
( \pm 0.54)\end{array}$ & $\begin{array}{l}96 \\
3.6 \\
( \pm 0.47)\end{array}$ \\
\hline
\end{tabular}

$\mathrm{n}=$ number of observations.

Standard error of mean shown as \pm .

group. Differing electrocardiographic patterns of the three groups could not be accounted for by the timing of the sampling from the date of the haemorrhage, as the three groups were similar in this respect.

The variety and incidence of electrocardiographic abnormalities in the present study are similar to those in other studies. The high concentration of deaths and very ill patients in the abnormal group suggests that electrocardiographic abnormalities may have some prognostic significance, and this aspect, particularly in relation to cerebral artery spasm, is discussed elsewhere (Neil-Dwyer, Cruickshank, and Bira, 1974, in press). The findings of the present investigation do not support those of Galloon et al. (1972) which indicated that cases with a changing electrocardiographic pattern were

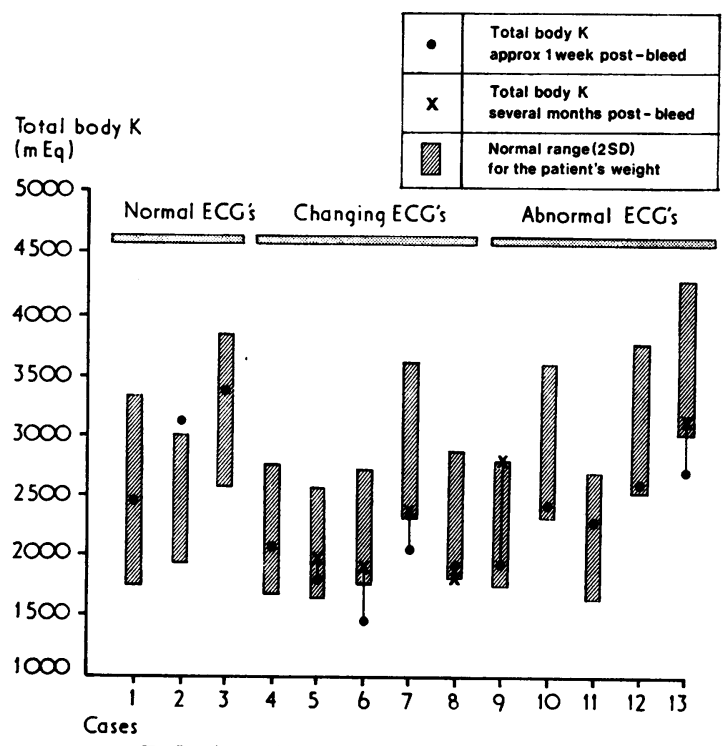

FIG. 2 Relation between electrocardiographic abnormality and total body exchangeable potassium approximately $I$ week after haemorrhage and in 6 cases at follow-up several months later.

at high risk. Clearly a case for catecholamines being responsible for the electrocardiographic abnormalities in subarachnoid haemorrhage can be made, though a cause and effect relation is not proven. Abnormally high catecholamine levels over the whole 2-week period in the abnormal group (Fig. I),

TABLE 8 Relation between electrocardiographic abnormalities and total body potassium approximately I week after subarachnoid haemorrhage and at follow-up several months later

\begin{tabular}{|c|c|c|c|c|c|c|c|c|c|}
\hline \multirow{2}{*}{\multicolumn{2}{|c|}{$\begin{array}{l}\text { Electrocardiogram type } \\
\text { Case } \\
\text { (sex and age) }\end{array}$}} & \multicolumn{3}{|c|}{ Normal electrocardiograms } & \multicolumn{5}{|c|}{ Changing electrocardiograms } \\
\hline & & $\begin{array}{l}I \\
M \\
I 3 y r\end{array}$ & $\begin{array}{l}2 \\
F \\
42 y r\end{array}$ & $\begin{array}{l}3 \\
M \\
54 y r\end{array}$ & $\begin{array}{l}4 \\
F \\
59 y r\end{array}$ & $\begin{array}{l}5 \\
F \\
I 8 y r\end{array}$ & $\begin{array}{l}6 \\
F \\
20 y r\end{array}$ & $\begin{array}{l}7 \\
M \\
54 y r\end{array}$ & $\begin{array}{l}8 \\
F \\
45 y r\end{array}$ \\
\hline \multicolumn{2}{|c|}{ Mean serum $K(m E q / l)$. } & $4 \cdot 3$ & $3 \cdot 6$ & 3.6 & $3 \cdot 6$ & $4 \cdot 2$ & $3 \cdot 6$ & $3 \cdot 7$ & $3 \cdot 8$ \\
\hline $\begin{array}{l}\text { Total body } \\
\text { potassium } \\
\text { (mEq) } \\
\text { I week after } \\
\text { subarachnoid } \\
\text { haemorrhage }\end{array}$ & $\begin{array}{l}\text { Observed } \\
\text { Predicted } \\
\text { K obs/ } \\
\text { K pred }\end{array}$ & $\begin{array}{l}2387 \\
2480 \\
( \pm 797)\end{array}$ & $\begin{array}{l}3209 \\
2437 \\
( \pm 541)\end{array}$ & $\begin{array}{l}3359 \\
3172 \\
( \pm 646)\end{array}$ & $\begin{array}{l}1977 \\
2192 \\
( \pm 54 I)\end{array}$ & $\begin{array}{l}1736 \\
2083 \\
( \pm 473)\end{array}$ & $\begin{array}{l}1418 \\
2200 \\
( \pm 473)\end{array}$ & $\begin{array}{l}2015 \\
2950 \\
( \pm 646)\end{array}$ & $\begin{array}{l}1909 \\
2320 \\
( \pm 54 I)\end{array}$ \\
\hline $\begin{array}{l}\text { Total body } \\
\text { potassium } \\
\text { (mEq) } \\
\text { several months } \\
\text { after } \\
\text { subarachnoid } \\
\text { haemorrhage }\end{array}$ & $\begin{array}{l}\text { Observed } \\
\text { Predicted } \\
\text { K obs/ } \\
\text { K pred }\end{array}$ & & & & & $\begin{array}{l}1987 \\
2083\end{array}$ & $\begin{array}{l}1906 \\
2200\end{array}$ & $\begin{array}{l}2344 \\
2950\end{array}$ & $\begin{array}{l}1788 \\
2320\end{array}$ \\
\hline
\end{tabular}

Two standard deviations from predicted level shown as \pm .

The ratio of observed against predicted total body $K=K$ obs/K pred. 
so unlike the normal stress response (Moore, 1959), support this view. Electrocardiographic features showing a particularly strong relation with urinary normetanephrin levels were peaked $T$ waves and a short PR interval, and with high urinary metanephrin levels peaked $P$ waves. This latter observation supports the finding of Lepeschkin et al. (I960) that intravenous adrenaline caused peaking of the $P$ waves. The relation between normetanephrin and the PR interval is in accord with observations on His bundle recordings (Damato et al., 1969) which showed that catecholamines caused a pronounced shortening of the PH component of the PR interval. The peaked $T$ wave - normetanephrin relation is consistent with the finding of Sparks et al. (1970) that $T$ wave peaking resulted from injection of noradrenaline into the coronary artery of the dog. Electrocardiographic abnormalities showing a weaker relation with high urinary catecholamine levels were $T$ wave inversion, long $Q T c$, tall $U$ waves, and $Q$ waves. These changes have been shown to occur in response to catecholamine administration (Hecht and Anderson, 1947; Lepeschkin et al., 1960; Haft et al., 1972). In attempting to correlate these electrocardiographic abnormalities with high urinary catecholamine levels, certain sources of possible error were considered. Firstly, as already mentioned, difficulty exists in interpreting the significance of urinary catecholamine levels. Secondly, the type of catecholamine is important. Sparks et al. (1970) demonstrated 3 classes of

TABLE 8 (Cont'd)

\begin{tabular}{|c|c|c|c|c|}
\hline $\begin{array}{l}9 \\
F \\
35 y r\end{array}$ & $\begin{array}{l}I 0 \\
M \\
43 y r\end{array}$ & $\begin{array}{l}I I \\
F \\
53 y r\end{array}$ & $\begin{array}{l}12 \\
M \\
43 y r\end{array}$ & $\begin{array}{l}13 \\
M \\
56 y r\end{array}$ \\
\hline 3.5 & $2 \cdot 9$ & $3 \cdot 2$ & $3 \cdot 8$ & $3 \cdot 8$ \\
\hline $\begin{array}{l}1950 \\
2225 \\
( \pm 541)\end{array}$ & $\begin{array}{l}2409 \\
2967 \\
( \pm 646)\end{array}$ & $\begin{array}{l}2274 \\
2140 \\
( \pm 54 I)\end{array}$ & $\begin{array}{l}2575 \\
3132 \\
( \pm 646)\end{array}$ & $\begin{array}{l}2677 \\
3660 \\
( \pm 646)\end{array}$ \\
\hline 0.88 & $0.8 \mathrm{I}$ & $I \cdot 07$ & 0.82 & 0.73 \\
\hline $\begin{array}{l}2783 \\
2225\end{array}$ & & & & $\begin{array}{l}3108 \\
3660\end{array}$ \\
\hline $1 \cdot 23$ & & & & 0.85 \\
\hline
\end{tabular}

catecholamine with differing actions upon the electrocardiogram. For example, adrenaline and noradrenaline caused $\mathrm{T}$ wave peaking, while normetanephrins and metanephrins gave rise to $T$ wave inversion. Complicated interactions of the three classes also occur. Thirdly, there is a pronounced individual variation in electrocardiographic response to any one type of catecholamine (Lepeschkin et al., 1960).

The maintained high urinary catecholamine concentration in the abnormal electrocardiogram group was accompanied by plasma cortisol levels which remained abnormally high throughout the 2-week period. These results differ from those of Eisalo et al. (1972) who observed a fall in plasma cortisol levels after the first few days. The high cortisol levels showed a statistically significant relation with only 3 electrocardiographic features: positive in the case of peaked $P$ waves and peaked $T$ waves, and negative for the PR interval. With regard to the latter relation, it is of interest to reflect on the rationale for giving steroids to cases of complete heart block (Stock, 1969); Lown et al. (1955) noted a long interval in Addison's disease, while Cushing's syndrome was associated with a short PR interval which appeared to correlate with urinary steroid levels. The appropriate treatment for these diseases resulted in a return of the PR interval to normal. Jenkins et al. (1969) demonstrated pituitary-adrenal dysfunction in subarachnoid haemorrhage, with high nocturnal plasma cortisol levels. In the present study nocturnal plasma cortisol levels were not measured.

Plasma potassium concentration is sometimes taken to indicate the body's potassium status. The body potassium is, however, located mainly within the cells, less than 3 per cent being in the extracellular fluid. Hence potassium status is only indirectly reflected by plasma potassium levels. In fact Croxson et al. (1972), Lockey et al. (1966), and many others have found no useful correlation between plasma and total body potassium; and this has been confirmed in this investigation. Comparing serial readings of total exchangeable body potassium related to total body weight is a valid process provided body weight does not alter significantly during the period of observation. This was the case in the present study. Hypokalaemia did not appear to be a factor in the production of electrocardiographic abnormalities in this study. In contrast, total body potassium estimated about one week after the haemorrhage was, with one exception, low in the changing and abnormal electrocardiogram groups. A second total body potassium estimation several months later, in 6 of the 9 with low total levels, showed that the deficit had been wholly or 
partially corrected in all but one patient in whom this remained unchanged.

Why potassium deficiency should have occurred in the first place is not immediately clear. No patient was on diuretic therapy and all had normal diets. Possible explanations are as follows: r) potassium deficiency was, for some reason, present before admission to hospital; 2) enforced bed rest caused muscle wasting, but this would have affected all cases in similar fashion; 3) high plasma corticosteroid levels associated with changing and abnormal electrocardiogram groups caused intracellular and renal potassium loss; and 4) protein catabolism associated with stress (not corticosteroid dependent) leads to renal potassium loss (Allison, I972). Though the first explanation cannot definitely be ruled out, the last two modes of potassium loss seem the most likely explanation for the low total body potassium observed in this study.

The mode of action of catecholamines upon the heart is not fully understood. Both transient and more permanent effects can occur. Transient effects stem from the property of catecholamines to modify cardiac electrical activity (Hoffman and Singer, 1967), in particular phases 2 and 3 of the monophasic action potential (Sparks et al., 1970), where an increase in the slope of phase 3 causes $T$ wave peaking and a decrease in the slope $T$ wave inversion. $T$ wave peaking sites (beta-receptors) and $T$ wave inverting sites (not alpha-receptors) exist (Sparks et al., 1970), and the possibility of adenyl cyclase (which stimulates cyclic AMP) being the beta-receptor was discussed by Sutherland, Robison, and Butcher (1968). The more permanent effects occur when the physiological action of catecholamines, if carried to excess, produce pathological changes. Cardiac myofibrillar degeneration, frequently focal and subendocardial, has been well described (Reichenbach and Benditt, 1970) in association with phaeochromocytomas or catecholamine administration. These authors also describe identical lesions occurring in the hearts of patients who died from subarachnoid haemorrhage. The ability of corticosteroids to sensitize the heart to the cardiotoxic effects of catecholamines (Raab, 1966; Selye, 1970) is probably an important factor in the production of electrocardiographic abnormalities in subarachnoid haemorrhage. This sensitizing action is almost certainly the result of potassium loss from the heart muscle, as a decrease in myocardial intracellular potassium content has been found to increase susceptibility to myofibrillar degeneration (Prioreschi, 1963; Bajusz and Jasmin, 1964). Other possible contributing factors to the cellular necrosis are relative anoxia resulting from increased oxygen requirements, and the ability of catecholamines to aggregate platelets, leading to thrombus formation and cellular death (Haft et al., I972).

It is suggested that the mechanism of production of transient and more permanent electrocardiographic abnormalities in subarachnoid haemorrhage is as follows. The haemorrhage, by causing local cerebral arteriolar spasm, gives rise to ischaemic lesions in the hypothalamus and surrounding area (Crompton, 1963; Smith, 1963). This causes sympathetic stimulation of the heart, directly via the cardiac nerves and indirectly via the adrenal medulla. Stimulation of the hypothalamus has been shown to give rise to electrocardiographic abnormalities and to myocardial lesions resembling those seen in subarachnoid haemorrhage (Greenhoot and Reichenbach, 1969; Melville et al., 1963). Such changes may be abolished by interruption of the sympathetic pathways in the high cervical region. Adrenalectomy, beta-blockade, or reserpine administration can prevent the development of electrocardiographic abnormalities and the myocardial lesions associated with simulated subarachnoid haemorrhage in animals (Burch et al., 1967; Connor, 1969; Offerhaus and van Gool, I969; Hawkins and Clower, I97I ; Hunt and Gore, 1972). Hypothalamic stimulation, through the pituitary adrenocortical axis, has an additional effect upon the heart; it results in increased corticosteroid production which in turn depletes myocardial intracellular potassium, thus potentiating the cardionecrotic effects of catecholamines. However, evidence for depletion of myocardial intracellular potassium in subarachnoid haemorrhage is only indirect, where a decrease in total body potassium, not reflected in serum levels, has been demonstrated. There is, therefore, much evidence to suggest that catecholamines are responsible for electrocardiographic abnormalities and myocardial lesions found in the human subject with subarachnoid haemorrhage, and that these changes are potentiated by increased corticosteroid activity which leads to loss of myocardial intracellular potassium.

We would like to thank Mr. F. C. Grimes, Dr. D. Ackery, and Mr. J. Brice for their help.

\section{References}

Allison, S. (1972). The metabolic response to injury. Medicine, II, 730.

Bajusz, E., and Jasmin, G. (1964). Influence of variations in electrolyte intake upon the development of cardiac necrosis produced by vasopressor amines. Laboratory Investigation, 13, 757 .

Burch, G. E., Sun, S. C., Colcolough, H. L., DePasquale, N. P., and Sohal, R. S. (1967). Acute myocardial lesions. Archives of Pathology, 84, 517. 
Byer, E., Ashman, R., and Toth, L. A. (1947). Electrocardiograms with large upright $\mathrm{T}$ waves and long $\mathrm{Q}-\mathrm{T}$ intervals. American Heart fournal, 33, 796.

Connor, R. C. R. (1969). Myocardial damage secondary to brain lesions. American Heart fournal, 78, 145.

Crompton, M. R. (1963). Hypothalamic lesions following the rupture of cerebral berry aneurysms. Brain, 86, 301 .

Cropp, G. J., and Manning, G. W. (1960). Electrocardiographic changes simulating myocardial ischemia and infarction associated with spontaneous intracranial haemorrhage. Circulation, 22, 25.

Croxson, M. S., Neutze, J. M., and John, M. B. (1972). Exchangeable potassium in heart disease: long-term effects of potassium supplements and amiloride. American Heart Fournal, 84, 53.

Damato, A. N., Lau, S. H., Helfant, R. H., Stein, E., Berkowitz, W. D. and Cohen, S. I. (I969). Study of atrioventricular conduction in man using electrode catheter recordings of His Bundle activity. Circulation, 39, 287.

Eisalo, A., Peräsalo, J., and Halonen, P. I. (I972). Electrocardiographic abnormalities and some laboratory findings in patients with subarachnoid haemorrhage. British Heart Fournal, 34, 217.

Finkelstein, D., and Nigaglioni, A. (I96I). Electrocardiographic alterations after neurosurgical procedures. American Heart fournal, 62, 772.

Flear, C. T. G., Cooke, W. T., Sivyer, A., and Domenet, J. (1963). Measurement of total exchangeable potassium. Clinica Chimica Acta, 8, 768.

Fluck, D. C. (1972). Catecholamines. British Heart fournal, $34,869$.

Galloon, S., Rees, G. A. D., Briscoe, C. E., Davies, S., and Kilpatrick, G. S. (1972). Prospective study of electrocardiographic changes associated with subarachnoid haemorrhage. British fournal of Anaesthesia, 44, 511 .

Greenhoot, J. H., and Reichenbach, D. D. (I969). Cardiac injury and subarachnoid haemorrhage. fournal of Neurosurgery, 30, $52 \mathrm{I}$.

Haft, J. I., Kranz, P. D., Albert, F. J., and Fani, K. (1972). Intravascular platelet aggregation in the heart induced by norepinephrine. Circulation, 46, 698.

Hawkins, W. E., and Clower, B. R. (I97I). Myocardial damage after head trauma and simulated intracranial haemorrhage in mice: the role of the autonomic nervous system. Cardiovascular Research, 5, 524.

Hecht, H. H., and Anderson, R. B. (1947). The influence of dibenamine on certain functions of the sympathetic nervous system in man. American fournal of Medicine, 3, 3.

Hersch, C. (1964). Electrocardiographic changes in subarachnoid haemorrhage, meningitis, and intracranial spaceoccupying lesions. British Heart fournal, 26, 785.

Hoffman, B. F., and Singer, D. H. (1967). Appraisal of the effects of catecholamines on cardiac electrical activity. Annals of the New York Academy of Sciences, 139, 914.

Hunt, D., McRae, C., and Zapf, P. (1969). Electrocardiographic and serum changes in subarachnoid hemorrhage. American Heart fournal, 77, 479.

Hunt, D., and Gore, I. (1972). Myocardial lesions following experimental intercranial hemorrhage: prevention with propranolol. American Heart fournal, 83, 232.

Iliynsky, B. V., and Astrakhantseva, S. P. (1967). Changes of ECG in acute disorders of the cerebral circulation as compared to the daily excretion of catecholamines and blood electrolytes. Terapevticheskit Arkhiv, 39, No. 4, 53.
Jenkins, J. S., Buckell, M., Carter, A. B., and Westlake, S. (1969). Hypothalamic - pituitary - adrenal function after subarachnoid haemorrhage. British Medical fournal, 4, 707.

Kreus, K-E., Kemilä, S. J., and Takala, J. K. (1969). Electrocardiographic changes in cerebrovascular accidents. Acta Medica Scandinavica, 185, 327.

Kung, L. S., Huang, T. K., Chu, H. Y., and Koang, N. K. (1958). The electrocardiogram in cerebrovascular accidents. Chinese Medical fournal, 76, 445.

Lepeschkin, E., Marchet, H., Schroeder, G., Wagner, R., de Paula e Silva, P., and Raab, W. (1960). Effect of epinephrine and norepinephrine on the electrocardiogram of 100 normal subjects. American fournal of Cardiology, 5, 594.

Lichtlen, P., and Schaub, F. (1962). EKG - Veränderungen bei cerebralem Insult. Cardiologia, 40, 159.

Lockey, E., Longmore, D. B., Ross, D. N., and Sturridge, M. F. (1966). Potassium and open-heart surgery. Lancet, I, 671 .

Lown, B., Arons, W. L., Ganong, W. F., Vazifdar, J. P., and Levine, S. A. (1955). Adrenal steroids and atrioventricular conduction. American Heart fournal, 50, 760.

Mattingly, D. (1962). A simple fluorimetric method of the estimation of free II - hydrocorticoids in human plasma. fournal of Clinical Pathology, 15, 374.

Melville, K. I., Blum, B., Shister, H. E., and Silver, M. D. (1963). Cardiac ischemic changes and arrhythmias induced by hypothalamic stimulation. American fournal of Cardiology, 12, 781.

Moore, F. D. (1959). Metabolic Care of the Surgical Patient, p. 82. Saunders, Philadelphia.

Moore, F. D. (1963). The Body Cell Mass and its Supporting Environment. Saunders, Philadelphia and London.

Neil-Dwyer, G., Cruickshank, J. M., and Brice, J. (1974). fournal of Neurological Science (in press).

Offerhaus, L., and van Gool, J. (1969). ECG changes and tissue catecholamines in experimental subarachnoid haemorrhage. Cardiovascular Research, 3, 433.

Prioreschi, P. (1963). Chlorides, potassium and experimental cardiac necrosis. Circulation Research, 12, 55.

Raab, W. (1966). Emotional and sensory stress factors in myocardial pathology. American Heart fournal, 72, 538.

Reichenbach, D. D., and Benditt, E. P. (1970). Catecholamines and cardiomyopathy. Human Pathology, 1, 125.

Sarner, M., and Crawford, M. D. (1965). Ruptured intracranial aneurysm. Lancet, 2, $125 \mathrm{I}$.

Selye, H. (1970). The evolution of the stress concept. American fournal of Cardiology, 26, 289.

Shuster, S. (1960). The electrocardiogram in subarachnoid haemorrhage. British Heart fournal, 22, 316.

Smith, B. (1963). Cerebral pathology in subarachnoid haemorrhage. fournal of Neurology, Neurosurgery and Psychiatry, 26, 535 .

Sodi-Pallares, D., Bisteni, A., Medrano, G. A., Testelli, M. R., and De Micheli, A. (I963). The polarizing treatment of acute myocardial infarction. Diseases of the Chest, 43, 424 .

Sparks, H. V., Hollenberg, M., Carriere, S., Funkenstein, D., Zakheim, R. M., and Barger, A. C. (I970). Sympathomimetic drugs and repolarization of ventricular myocardium of the dog. Cardiovascular Research, 4, 363.

Stock, J. P. P. (1969). Diagnosis and Treatment of Cardiac Arrhythmias, p. 206. Butterworths, London.

Stott, A. W., and Robinson, R. (1966). The determination of urinary amines by one-dimensional paper chromatography. fournal of Clinical Pathology, 19, 487. 
Sutherland, E. W., Robison, G. A., and Butcher, R. W. (1968). Some aspects of the biological role of adenosine 3, 5-monophosphate (cyclic AMP). Circulation, 37, 279.

Tomomatsu, T., Ueba, Y., Matsumoto, T., Oda, M., Ikoma, T., Kondo, Y., and Ijiri, Y. (1964). Electrocardiographic observations and urinary excretion of catecholamines in cardiovascular disorders. Fapanese Circulation fournal, 28, 905.
Wasserman, F., Choquette, G., Cassinelli, R., and Bellet, S. (1956). ECG observations in patients with cerebrovascular accidents. American fournal of the Medical Science, 231, 502.

Requests for reprints to Dr. G. Neil-Dwer, Wessex Neurosurgical Unit, Southampton General Hospital, Shirley, Southampton SO9 $4 \mathrm{XY}$. 